This item was submitted to Loughborough's Research Repository by the author.

Items in Figshare are protected by copyright, with all rights reserved, unless otherwise indicated.

\title{
Biosorption of azo dyes by raspberry-like Fe304@yeast magnetic microspheres and their efficient regeneration using heterogeneous Fenton- like catalytic processes over an up-flow packed reactor
}

\section{PLEASE CITE THE PUBLISHED VERSION}

http://dx.doi.org/10.1007/s11144-015-0854-z

\section{PUBLISHER}

(C) Akadémiai Kiadó Zrt

\section{VERSION}

AM (Accepted Manuscript)

\section{PUBLISHER STATEMENT}

This work is made available according to the conditions of the Creative Commons Attribution-NonCommercialNoDerivatives 4.0 International (CC BY-NC-ND 4.0) licence. Full details of this licence are available at: https://creativecommons.org/licenses/by-nc-nd/4.0/

\section{LICENCE}

CC BY-NC-ND 4.0

\section{REPOSITORY RECORD}

Song, Rui, Bo Bai, Gianluca Li Puma, Honglun Wang, and Yourui Suo. 2015. "Biosorption of Azo Dyes by Raspberry-like Fe304@yeast Magnetic Microspheres and Their Efficient Regeneration Using Heterogeneous Fenton-like Catalytic Processes over an Up-flow Packed Reactor". figshare. https://hdl.handle.net/2134/19059. 


\title{
Biosorption of Azo Dyes by Raspberry-Like $\mathrm{Fe}_{3} \mathrm{O}_{4} @$ Yeast Magnetic Microspheres and Their Efficient Regeneration Using Heterogeneous Fenton-like Catalytic Processes over an Up-Flow Packed Reactor
}

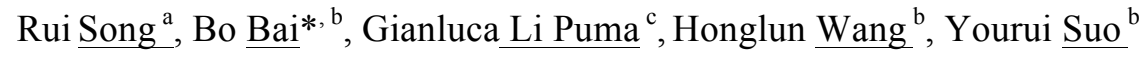 \\ ${ }^{a}$ College of Environmental Science and Engineering, Chang'an University, Xi'an, 710054, P.R. \\ China; \\ ${ }^{b}$ Northwest Plateau Institute of Biology, Chinese Academy of Sciences, Xining, 810001, People's \\ Republic of China; \\ ${ }^{\mathrm{c}}$ Environmental Nanocatalysis and Photoreaction Engineering, Department of Chemical Engineering, \\ Loughborough University, Loughborough, LE11 3TU, United Kingdom. \\ * Corresponding author: Tel: +86298233 9052; Fax:+86 298233 9961; Email: baibo@chd.edu.cn
}




\begin{abstract}
Raspberry-like $\mathrm{Fe}_{3} \mathrm{O}_{4} @$ yeast composite microspheres, whose properties integrate the biosorption features of yeast cells with the excellent magnetic and catalytic properties of $\mathrm{Fe}_{3} \mathrm{O}_{4}$ nanoparticles were synthesized by a simple electrostatic-interaction-driven self-assembly heterocoagulation. They were successfully applied in an up-flow packed column for the removal of the model water contaminant methylene blue dye (MB) by consecutive bioadsorption-heterogeneous Fenton oxidation cycles. The as-synthesized $\mathrm{Fe}_{3} \mathrm{O}_{4} @$ yeast composites were characterized by field emission scanning electron microscopy (FE-SEM), energy-dispersive spectroscopy (EDS), powder X-ray diffraction (XRD) and Fourier transform infrared (FT-IR) spectroscopy. The adsorption process was controlled by the electrostatic interactions between the adsorbent and contaminant. The adsorbent is suitable for the adsorption of positively charged compounds at mildly acidic $\mathrm{pH}$, neutral and alkaline $\mathrm{pH}$, with the highest performance observed at alkaline $\mathrm{pH}$. The experimental breakthrough curves measured at different influent $\mathrm{MB}$ concentration, flow rate, bed height and $\mathrm{pH}$ were modeled by the Yoon-Nelson model. The in-situ regeneration of the contaminant-loaded $\mathrm{Fe}_{3} \mathrm{O}_{4} @$ yeast microspheres and their reuse in multiple cycles was demonstrated by triggering the heterogeneous Fenton-like reaction catalyzed by the supported magnetite. The raspberry-like $\mathrm{Fe}_{3} \mathrm{O}_{4} @$ yeast magnetic microsphere should be a promising and practical adsorbent for removal and destruction of positively charged organic compounds in wastewater.
\end{abstract}

Keywords: Yeast; Iron oxide; Fixed-bed; Fenton-like reaction; Regeneration; Wastewater 


\section{Introduction}

Organic azo dyes represent more than half of all colouring compounds used by the world textile industry. It has been estimated that $15 \%$ of this is released into the environment without an appropriate treatment [1]. Organic azo dyes in wastewater have been classified as priority pollutants particularly owing to the toxicity of their microbial metabolites, which can be mutagenic, genotoxic and carcinogenic [2]. Traditional physico-chemical treatment techniques such as absorption, oxidization, and flotation are usually ineffective to treat low azo dyes concentrations [3]. Biological materials such as micro-organisms (including bacteria, fungi, and algae) [4] and biomass can remove a broad range of azo dyes [5-6]. However, an efficient and sustainable method for pollution abatement that uses biosorbents requires the regeneration and reuse of the sorbent, the destruction of the sorbed/desorbed pollutants, and the safe disposal of the sorbent to the environment. Yeast is an effective biosorbent [7] which meets several green requirements for large-scale pollutant removal including, high selectivity, efficiency, cost-effectiveness, availability and biocompatibility.

Heterogeneous Fenton processes are powerful method for the destruction of azo dyes in aqueous solutions [8-10], especially, those catalyzed by nano-sized magnetite $\left(\mathrm{Fe}_{3} \mathrm{O}_{4}\right)$ particles [11-13]. In this system, the octahedral site of the magnetite structure can easily accommodate both $\mathrm{Fe}^{2+}$ and $\mathrm{Fe}^{3+}$, allowing the $\mathrm{Fe}$ species to be reversibly oxidized and reduced producing $\bullet \mathrm{OH}$ radicals when in the presence of $\mathrm{H}_{2} \mathrm{O}_{2}$ [14-15]. Furthermore, $\mathrm{Fe}_{3} \mathrm{O}_{4}$ nanoparticles can be easily separated from the reaction system by a simple magnetic separation procedure.

The treatment of contaminated streams by Fenton oxidation with slurry suspensions of Iron oxide can be inefficient since uses large volumes of reagents/catalyst, the water matrix can inefficiently consume $\cdot \mathrm{OH}$ radicals and large contact times are often required. In contrast, the efficiency of the 
heterogeneous Fenton process for the treatment of wastewater can be increased significantly by applying an enrichment or pre-concentration sorption method prior to the oxidation of the contaminants by the Fenton process on immobilized magnetite.

The combination of an inorganic catalyst with a biological sorbent into hybrid or composite material is attracting increasing attention as it enables new functional properties, which are not possible in their starting components. For example a new class of complex nano-structured hybrid microspheres with a raspberry-like structure can provide a unique micro/nano-environment which has found new applications in the material, chemical, medical and environmental sectors [16-20]. Bai et al. have synthesized novel raspberry-like $\mathrm{TiO}_{2} @$ yeast composites, which were effective photocatalysts for the degradation of dyes [21]. The raspberry-shape provided larger surface area of the supported catalyst. However, such materials required the use of UV light photons, which restrict their technological development.

In this study, we investigate a new composite material, made of raspberry-like $\mathrm{Fe}_{3} \mathrm{O}_{4} @$ yeast microspheres that integrate the biosorption features of yeast cells with the excellent magnetic and catalytic properties of $\mathrm{Fe}_{3} \mathrm{O}_{4}$ nanoparticles, and its application for the effective removal of contaminants from wastewater by consecutive biosorption and heterogeneous Fenton oxidation/regeneration cycles. In this new material, the traditional magnetic $\mathrm{Fe}_{3} \mathrm{O}_{4}$ nano-particles were anchored on the yeast surface by an electrostatic self-assembly process that produced a heterogeneous Fenton's catalyst with an unique raspberry-like microstructure. The effectiveness of the raspberry-like $\mathrm{Fe}_{3} \mathrm{O}_{4} @$ yeast composite microspheres for the removal of the cationic dye methylene blue (MB), a model compound used in the standardization of degradation experiments (e.g., ISO 10678:2010), was investigated in a continuous, up-flow, fixed-bed column system. The modeling of the adsorption 
phenomena and breakthrough profiles allowed the prediction of the breakthrough time after which the in-situ regeneration of the composite material and the decomposition of MB was triggered through the heterogeneous Fenton reaction catalyzed by the $\mathrm{Fe}_{3} \mathrm{O}_{4}$ nanoparticles. The robustness of the composite catalytic biosorbent was assessed for multiple adsorption/regeneration cycles.

\section{Materials and methods}

\subsection{Materials}

All chemicals used were of analytical grade and used without further purification. The powdered yeast was purchased from Angel Yeast Company. Ferric chloride hexahydrate $\left(\mathrm{FeCl}_{3} \cdot 6 \mathrm{H}_{2} \mathrm{O}\right)$, absolute ethanol (95 wt \%), formaldehyde $\left(\mathrm{CH}_{2} \mathrm{O}\right)$, hydrazine hydrate $\left(\mathrm{N}_{2} \mathrm{H}_{4} \cdot \mathrm{H}_{2} \mathrm{O}\right)$, methylene blue (MB), and sulfuric acid $\left(\mathrm{H}_{2} \mathrm{SO}_{4}\right)$ were provided by Xi'an Chemical Agent Corp. Double deionized water was used throughout all the experiments.

\subsection{Preparation of $\mathrm{Fe}_{3} \mathrm{O}_{4} @$ yeast composite microspheres}

$\mathrm{Fe}_{3} \mathrm{O}_{4}$ nanoparticles were firstly synthesized through a hydrothermal method using $\mathrm{FeCl}_{3} \cdot 6 \mathrm{H}_{2} \mathrm{O}$ as a single iron source. Briefly, $\mathrm{FeCl}_{3} \cdot 6 \mathrm{H}_{2} \mathrm{O}(1.20 \mathrm{~g}), \mathrm{CH}_{2} \mathrm{O}(2 \mathrm{~mL})$ and $\mathrm{N}_{2} \mathrm{H}_{4} \cdot \mathrm{H}_{2} \mathrm{O}(5 \mathrm{~mL})$ were dissolved in deionized water $(40 \mathrm{~mL})$ under magnetic stirring for $15 \mathrm{~min}$. The solution was then transferred to a Teflon-lined stainless-steel autoclave and heated at $120{ }^{\circ} \mathrm{C}$. After $5 \mathrm{~h}$ of reaction, the autoclave was cooled to room temperature. The black $\mathrm{Fe}_{3} \mathrm{O}_{4}$ nanoparticles were collected magnetically and washed with three consecutive cycles of ethanol and distilled water and then dried in vacuum at $80^{\circ} \mathrm{C}$ for $1 \mathrm{~h}$. The dried $\mathrm{Fe}_{3} \mathrm{O}_{4}$ nanoparticles were then re-dispersed in $150 \mathrm{~mL}$ of distilled water and the $\mathrm{pH}$ adjusted to 5 by adding $\mathrm{H}_{2} \mathrm{SO}_{4}(1 \mathrm{M})$. The suspension was stirred for 30 min to promote the de-aggregation of the $\mathrm{Fe}_{3} \mathrm{O}_{4}$ nanoparticles. In a separate vessel, $1.000 \mathrm{~g}$ of yeast powder was washed with distilled water and ethanol three times, respectively. It was dispersed in $150 \mathrm{~mL}$ of distilled water and the $\mathrm{pH}$ was adjusted to 5 by adding $\mathrm{H}_{2} \mathrm{SO}_{4}(1 \mathrm{M})$. The suspension was magnetically stirred for 30 min to facilitate 
the dispersion of the yeast particles. Finally, the suspensions of $\mathrm{Fe}_{3} \mathrm{O}_{4}$ nanoparticles and yeast were blended, under continuous stirring for $1 \mathrm{~h}$ at room temperature, and then the suspension was left for 3 $\mathrm{h}$ without further stirring, during which raspberry-like $\mathrm{Fe}_{3} \mathrm{O}_{4} @$ yeast microspheres were produced via electrostatic self-assembly. The products were collected with a magnet, washed with distilled water and ethanol three times, and then dried at $80{ }^{\circ} \mathrm{C}$ for further use.

\subsection{Material characterization}

The particle size and surface morphology of the samples were observed by a Philips XL 30 field emission scanning electron microscope (FE-SEM). The elemental composition of the composite microspheres was determined with the energy-dispersive spectroscopy (EDS) of the FE-SEM. The crystallographic structures of the samples were identified by powder X-ray diffraction (XRD) using $\mathrm{Cu} \mathrm{K} \alpha$ radiation $(\lambda=0.15418 \mathrm{~nm})$ at a scanning rate of $0.02^{\circ} / \mathrm{min}$. Fourier-transform infrared (FT-IR) spectra of samples were recorded on a Bio-Rad FTS135 spectrometer in the range $500-4000 \mathrm{~cm}^{-1}$ using a $\mathrm{KBr}$ wafer technique, to study the formation and ripening mechanism of the samples.

\subsection{Up-flow fixed-bed adsorption experiments}

The adsorption and regeneration performance of the $\mathrm{Fe}_{3} \mathrm{O}_{4} @$ yeast composites was investigated in up-flow fixed-bed columns made from glass $(12 \mathrm{~cm}$ high, $0.8 \mathrm{~cm}$ internal diameter) operated in continuous flow. A stock solution of $\mathrm{MB}(1000 \mathrm{mg} / \mathrm{L})$ was prepared and further diluted to the required feed concentration in each experiment. The effect of the influent concentration $(100,150$ and

$200 \mathrm{mg} / \mathrm{L})$, flow rate $(5,10$, and $15 \mathrm{~mL} / \mathrm{min})$, bed depth $(1.2,2.4$ and $3.6 \mathrm{~cm}$, corresponding to 0.1 , 0.2 and $0.3 \mathrm{~g}$ of adsorbent, respectively) and $\mathrm{pH}(3,5,7,9,11)$ on the removal of $\mathrm{MB}$ in the columns was investigated. The $\mathrm{pH}$ of the dye solutions was adjusted by adding $\mathrm{NaOH}$ and $\mathrm{H}_{2} \mathrm{SO}_{4}$, respectively. Samples collected from the inlet/outlet of the columns at regular intervals were analyzed using a 
Jenway $6405 \mathrm{UV}-$ vis spectrophotometer at $664 \mathrm{~nm}$. All of the experiments were performed in triplicate and at room temperature.

\subsection{Regeneration experiment}

After each adsorption cycle, the exhausted column bed was rinsed by flowing $100 \mathrm{~mL}$ double deionized water in the upward direction at the same flow rate used during the adsorption cycle. Then the in-situ regeneration of the $\mathrm{Fe}_{3} \mathrm{O}_{4} @$ ayeast bed was triggered by flowing a $10 \% \mathrm{H}_{2} \mathrm{O}_{2}$ aqueous solution through the column bed in the upward direction at a flow rate of $1 \mathrm{~mL} / \mathrm{min}$ for $1 \mathrm{~h}$. The column was finally rinsed with double deionized water to remove the residual $\mathrm{H}_{2} \mathrm{O}_{2}$. After the completion of regeneration procedure, the bed was reused for the next adsorption-regeneration cycle, up to three consecutive cycles.

\section{Results and discussion}

\subsection{Characterization and mechanism}

\section{Figure 1}

Figure 1 shows typical FE-SEM images of the original yeast and the as-obtained $\mathrm{Fe}_{3} \mathrm{O}_{4} @$ yeast composite microspheres under different magnifications. The original yeast (Figure 1(a)) shows cells with a smooth surface and ellipsoidal shape with regular diameter (length $4.0 \pm 0.2 \mu \mathrm{m}$; width $2.6 \pm$ $0.2 \mu \mathrm{m}$ ). The $\mathrm{Fe}_{3} \mathrm{O}_{4} @$ yeast composite microspheres (Figure 1(b)) maintained the ellipsoidal shape of the original yeast with the rough surface morphology and relatively good monodispersity. The dimensions of the composite microspheres slightly increased (length $4.5 \pm 0.2 \mu \mathrm{m}$; width $3.0 \pm 0.2 \mu \mathrm{m}$ ) suggesting that the $\mathrm{Fe}_{3} \mathrm{O}_{4}$ nanoparticles (on average $20 \mathrm{~nm}$, inset in Figure 1(c)) were successfully attached onto the surface of yeast. The higher magnification image (Figure 1(c)), shows a rough surface decorated with numerous $\mathrm{Fe}_{3} \mathrm{O}_{4}$ nanoparticles with exposed yeast bare areas. Furthermore, 
each of the composite microspheres approached a distinct raspberry-like morphology.

The EDS analysis of the composite microspheres is shown in Figure S1 of Supporting Information (SI).

The $\mathrm{C}$ and in part the $\mathrm{O}$ peaks resulted from the original yeast cell wall, the $\mathrm{Fe}$ and part of the $\mathrm{O}$ originated from the $\mathrm{Fe}_{3} \mathrm{O}_{4}$ supported nanoparticles, and $\mathrm{Pt}$ arose from the metal spraying before SEM studies. No other elements were detected, indicating that the final product was impurities free.

\section{Figure 2}

Figure 2 shows the XRD patterns of the original yeast, pure $\mathrm{Fe}_{3} \mathrm{O}_{4}$ nanoparticles and the $\mathrm{Fe}_{3} \mathrm{O}_{4} @$ yeast composite microspheres, respectively. The amorphous yeast showed only a broad peak at around $2 \theta=$ $20^{\circ}$ (Figure 2a). The strong and sharp diffraction peaks at $18.4^{\circ}, 30.3^{\circ}, 35.6^{\circ}, 37.3^{\circ}, 43.2^{\circ}, 53.4^{\circ}, 57.2^{\circ}$ and $62.9^{\circ}$ in the patterns of the $\mathrm{Fe}_{3} \mathrm{O}_{4}$ nanoparticles (Figure 2b) were indexed as (110), (220), (311), (222), (400), (422), (511) and (440) respectively of the face center-cubic phase of $\mathrm{Fe}_{3} \mathrm{O}_{4}$ (JCPDS card No. 19-0629) which agree with literature [22-23]. The broad peak at $2 \theta=20^{\circ}$ of the $\mathrm{Fe}_{3} \mathrm{O}_{4} @$ yeast composite microspheres (Figure 2c) originated mainly by the amorphous structure of yeast. The remaining peaks supported the incorporation of the $\mathrm{Fe}_{3} \mathrm{O}_{4}$ nanoparticles in the composite and no other diffraction peaks were found in the range investigated indicating the high purity of the products. The intensity of the $\mathrm{Fe}_{3} \mathrm{O}_{4}$ peaks in the microspheres were lower than those of the pure $\mathrm{Fe}_{3} \mathrm{O}_{4}$ nanoparticles, which may result from the smaller number of $\mathrm{Fe}_{3} \mathrm{O}_{4}$ nanoparticles supported on the yeast surface [24, $25]$ and their good monodispersion surface traits $[26,27]$.

The ferromagnetic properties of the $\mathrm{Fe}_{3} \mathrm{O}_{4} @$ yeast composite microspheres in aqueous solution are shown in Figure S2 (SI). The $\mathrm{Fe}_{3} \mathrm{O}_{4} @$ yeast composite microspheres $(40 \mathrm{~g} / \mathrm{L})$ were dispersed in deionized water in a cuvette forming a stable suspension (Figure S2 (a)). Under the influence of a magnetic field, there was a rapid separation of the $\mathrm{Fe}_{3} \mathrm{O}_{4} @$ yeast composite particles to the wall of the 
cuvette, which yielded an almost colorless aqueous solution (Figure S2 (b) (SI)). This indicated that the $\mathrm{Fe}_{3} \mathrm{O}_{4}$ nanoparticles were successfully incorporated onto the surface of the yeast hosts endowing the yeast cells with magnetic properties allowing easy separation, recovery and reuse. The black colour imparted by the $\mathrm{Fe}_{3} \mathrm{O}_{4}$ nanoparticles to the ivory yeast in the composite further supports the successful incorporation of $\mathrm{Fe}_{3} \mathrm{O}_{4}$ nanoparticles on the yeast surface.

\section{Figure 3}

The bonding forces acting between the nanoparticles and the yeast were investigated by FT-IR (Figure 3). The broad and intense peaks in the region from 550 to $650 \mathrm{~cm}^{-1}$ of the $\mathrm{Fe}_{3} \mathrm{O}_{4}$ nanoparticles (Figure 3(a)) are assigned to the Fe-O band. The peaks at around $3300-3700 \mathrm{~cm}^{-1}$ and $1384 \mathrm{~cm}^{-1}$ belong to $\mathrm{OH}$ stretching vibrations and to the $\mathrm{H}-\mathrm{O}-\mathrm{H}$ bending band, suggesting that $\mathrm{H}_{2} \mathrm{O}$ molecules adsorbed on the surface of $\mathrm{Fe}_{3} \mathrm{O}_{4}$ [28]. The additional broad peaks at 3340, 1461, 1360, 1074 and 894 $\mathrm{cm}^{-1}$ may result from residual hydrazine hydrate remaining from the synthesis process. Regarding the yeast (Figure 3(b)), the broad and intense peaks at 3292, 2926, 1641, 1384 and $1074 \mathrm{~cm}^{-1}$ are assigned to the $\mathrm{N}-\mathrm{H}$ stretching and bending vibration, the $\mathrm{CH}_{2}$ asymmetric and symmetric stretching vibration, the amide group, $\mathrm{C}=\mathrm{O}$ stretching vibration, and the $\mathrm{P}=\mathrm{O}$ stretching vibration, respectively [29-31]. In the $\mathrm{Fe}_{3} \mathrm{O}_{4} @$ yeast spectra (Figure 3(c)), except for the characteristic absorption peak of yeast, a peak appeared in the range of 550 to $650 \mathrm{~cm}^{-1}$. Moreover, the characteristic peaks of yeast at $3292 \mathrm{~cm}^{-1}, 1641 \mathrm{~cm}^{-1}$ and $1054 \mathrm{~cm}^{-1}$ shifted to $3310 \mathrm{~cm}^{-1}, 1656 \mathrm{~cm}^{-1}$, and $1064 \mathrm{~cm}^{-1}$ respectively in the $\mathrm{Fe}_{3} \mathrm{O}_{4} @$ yeast composite microspheres, suggesting that the amino $\left(-\mathrm{NH}_{2}\right)$, carboxyl (-COO-) and phosphate $\left(-\mathrm{OPO}_{3}{ }^{2-}\right)$ groups played important roles in the anchoring of the $\mathrm{Fe}_{3} \mathrm{O}_{4}$ nanoparticles to the yeast surface.

Based on the above analysis, we propose a formation mechanism of $\mathrm{Fe}_{3} \mathrm{O}_{4} @$ yeast composite 
microspheres (Figure $\mathrm{S} 4$ (a) (SI)). After synthesis of $\mathrm{Fe}_{3} \mathrm{O}_{4}$ nanoparticles by the hydrothermal route the attachments of the nanoparticles onto the surface of yeast is driven by the electrostatic-interaction, self-assembly heterocoagulation between yeast cores and satellite $\mathrm{Fe}_{3} \mathrm{O}_{4}$ nanoparticles. Specifically, at the synthesis $\mathrm{pH}=5$, the $\mathrm{Fe}_{3} \mathrm{O}_{4}$ nanoparticles are positively charged $\left(\mathrm{pH}_{\text {iep }} 6.5\right.$, [32] ) and the yeast is negatively charged $\left(\mathrm{pH}_{\text {iep }} 3.0\right.$, [33]). Therefore, the opposite zeta-potentials of $\mathrm{Fe}_{3} \mathrm{O}_{4}$ nanoparticles and yeast in the range of $\mathrm{pH} 3.0 \sim 6.5$ provides a window to assemble them together. The inherent functional groups in the yeast cell wall, including phosphomannan, mannan, glucan, proteins and dextran play a significant role in the fabrication of the raspberry-like structure of the composite, since the abundant hydrophilic anion groups including $-\mathrm{NH}-,-\mathrm{COO}-$, and $-\mathrm{OPO}_{3}{ }^{2-}[34,35]$ can accumulate more negative charges on the surface of the yeast [36]. Hereby, the positively charged $\mathrm{Fe}_{3} \mathrm{O}_{4}$ nanoparticles can spontaneously attach with the negatively charged yeast, and gradually embed onto the external surface of the yeast, eventually forming the $\mathrm{Fe}_{3} \mathrm{O}_{4} @$ yeast composite microspheres with a raspberry-like structure.

\subsection{Fixed-bed column studies}

The partially uncovered yeast surface of the raspberry-like $\mathrm{Fe}_{3} \mathrm{O}_{4} @$ yeast microspheres drives the adsorption of water contaminants. The yeast surface is usually negatively charged $\left(\mathrm{pH}_{\text {iep }} 3.3\right)$ in consequence, positively charged water contaminants such as cationic dyes are readily sorbed. To demonstrate such effect, the sorption of MB from aqueous solution was investigated in a continuous, up-flow, fixed-bed adsorption/regeneration system. The breakthrough curves were defined by the ratio of effluent and influent MB concentrations $\left(C_{\mathrm{t}} / C_{0}\right)$ versus time $(t)$. The breakthrough time $\left(t_{\mathrm{b}}\right.$, time to reach $1 \mathrm{mg} / \mathrm{L} \mathrm{MB}$ in the effluent) and the bed exhaustion time or saturation time ( $t_{\mathrm{e}}$, time to reach $99 \%$ of the influent concentration in the effluent) were used to monitor the bed performance. To 
analyze the continuous flow, adsorption data included the evaluation of (a) the effluent volume $V_{\text {eff }}$ (mL) (Eq. 1); (b) the total loading of MB to the column $q_{\text {tot }}(\mathrm{mg}$ ) (Eq. 2) at a given flow rate and influent concentration; (c) the total amount of MB fed to the column $m_{\text {tot }}(\mathrm{mg}$ ) (Eq. 3); (d) the total percentage removal efficiency $\varphi$ of MB (Eq. 4); and (e) the equilibrium column loading $q_{\mathrm{e}}(\mathrm{mg} / \mathrm{g}$ ) (Eq. $5)$.

$$
\begin{gathered}
V_{\mathrm{eff}}=F \cdot t_{\mathrm{e}} \\
q_{t o t}=\frac{F A}{1000}=\frac{F}{1000} \int_{t=0}^{t=t_{t o t}} C_{a d} d t \\
m_{t o t}=\frac{C_{0} F t_{t o t}}{1000} \\
\varphi \%=\frac{q_{t o t}}{m_{t o t}} \times 100 \\
q_{e}=\frac{q_{t o t}}{m}
\end{gathered}
$$

Where $F$ is the volumetric flow rate $(\mathrm{mL} / \mathrm{min}), A$ is the area under the breakthrough curve, $C_{\text {ads }}(\mathrm{mg} / \mathrm{L})$ is the adsorbed $\mathrm{MB}$ concentration and $m$ is the amount of $\mathrm{Fe}_{3} \mathrm{O}_{4} @$ ayeast in the fixed bed $(\mathrm{g})$, respectively.

\section{Table 1}

\subsubsection{Influence of influent dye concentration, flow rate, bed height and mass transfer}

\section{Figure 4}

The breakthrough curves of MB for an influent dye concentration varying from 100 to $200 \mathrm{mg} / \mathrm{L}$ are shown in figure 4(a). In these experiments, the flow rate, bed height, and $\mathrm{pH}$ were kept constant at 5 $\mathrm{mL} / \mathrm{min}, 1.2 \mathrm{~cm}$ and 7 , respectively. The adsorption data and the parameters are also presented in Table 1. The observed breakthrough curves followed the typical S-shaped profile. However, a near linear profile was observed when the influent $\mathrm{MB}$ concentration increased to $200 \mathrm{mg} / \mathrm{L}$. The breakthrough and exhaustion times decreased with increasing influent dye concentration due to the 
faster rate of sorbent saturation. When $C_{0}$ increased from 100 to $200 \mathrm{mg} / \mathrm{L}$, the equilibrium column loading $\left(q_{\mathrm{e}}\right)$ decreased from 400.5 to $191.1 \mathrm{mg} / \mathrm{g}$ (Table 1) which suggests mass transfer limitations. In consequence, the bed exhaustion is reached before the complete saturation of the adsorbent. Simultaneously, the percent removal of MB for the tested influent concentrations decreased from $59.3 \%$ to $54.6 \%$.

The effect of flow rate (Figure 4(b) and Table 1) was examined by varying it from 5 to $15 \mathrm{~mL} / \mathrm{min}$ while $C_{0}$, bed height and $\mathrm{pH}$ were kept constant at $100 \mathrm{mg} / \mathrm{L}, 1.2 \mathrm{~cm}$, and 7 , respectively. The breakthrough curves became steeper and shifted towards shorter times as the flow rate increased, while the breakthrough time and the exhaustion time decreased from 24 to 9 min and from 135 to 35 min, respectively. Furthermore, $q_{\mathrm{e}}$ and $\varphi$ decreased as the flow rate increased, suggesting a slow intraparticle adsorption kinetics compared with the column saturation dynamics. Lower flow rates and longer residence time of $\mathrm{MB}$ results in a more efficient diffusion process through the sorbent and therefore a higher equilibrium column loading.

The effect of bed height on MB removal (Figure 4(c) and Table 1) was investigated at constant flow rate of $5 \mathrm{~mL} / \mathrm{min}$ and $100 \mathrm{mg} / \mathrm{L}$ influent dye concentration. An increase of the breakthrough time, exhaustion time and percentage removal, was observed, when the bed height rose from 1.2 to $3.6 \mathrm{~cm}$ (loading of 0.1 to $0.3 \mathrm{~g}$ of $\mathrm{Fe}_{3} \mathrm{O}_{4} @$ yeast) which results from the larger sorbent total mass. The significant reduction in the loading capacity observed with bed height was ascribed to an increase of pressure drop through the bed, which progressively decreases the rate of intraparticle diffusion.

The equilibrium sorption capacity of the $\mathrm{Fe}_{3} \mathrm{O}_{4} @$ yeast composite microspheres from batch recirculation experiments at $C_{0}$ equal to $100 \mathrm{mg} / \mathrm{L}$ and $\mathrm{pH} 7$ was $403.2 \mathrm{mg} / \mathrm{g}$, which suggest that MB mass transfer was negligible only at $C_{0}=100 \mathrm{mg} / \mathrm{L}, Z=1.2 \mathrm{~cm}$ and $\mathrm{pH}=7$ (Table 1). 


\subsubsection{Influence of $\mathrm{pH}$}

In these experiments, the $\mathrm{pH}$ of $\mathrm{MB}$ solution fed to the bed was fixed at 3, 5, 7, 9, and 11, while $C_{0}$, flow rate and bed height were kept constant at $100 \mathrm{mg} / \mathrm{L}, 5 \mathrm{~mL} / \mathrm{min}$, and $1.2 \mathrm{~cm}$, respectively. The results (Figure 4(d) and Table 1) show that the adsorption capacity and dye removal rate increased with an increase of $\mathrm{pH}$. Bed exhaustion occurred at 35, 60, 135, 255 and $355 \mathrm{~min}$ for $\mathrm{pH}$ of 3.0, 5.0, 7.0, 9.0 and 11.0 respectively. This phenomenon is governed by the electrostatic interaction between the dye and the surface charge of the adsorbent [37]. The adsorption of cationic dyes is favored at $\mathrm{pH}>\mathrm{pH}_{\text {iep }}\left(\mathrm{pH}_{\mathrm{iep}}=\right.$ isoelectric point, e.g. on $\mathrm{COO}-$ groups) and anionic dyes at $\mathrm{pH}<\mathrm{pH}_{\text {iep }}$ (e.g. on Lewis-base-type basal plane sites) [38]. MB is a cationic dye, which exists in solution in the form of positively charged ions. The surface properties of the yeast cores $\left(\mathrm{pH}_{\text {iep }}=3.3\right)$ and $\mathrm{Fe}_{3} \mathrm{O}_{4}$ nanoparticles $\left(\mathrm{pH}_{\text {iep }}=6.8\right)$ are also affected by $\mathrm{pH}$. At $\mathrm{pH} 3$, the surface charge of both yeast and $\mathrm{Fe}_{3} \mathrm{O}_{4}$ is positive, and thus the abundance of $\mathrm{H}^{+}$compete with the cationic $\mathrm{MB}$ molecules, reducing the adsorption capacity of the bed causing a rapid breakthrough. At $\mathrm{pH} 5$, the yeast surface has negative and the $\mathrm{Fe}_{3} \mathrm{O}_{4}$ nanoparticles have positive charge, which increases the adsorption of $\mathrm{MB}$ through the surface of the yeast resulting in a longer breakthrough time. At $\mathrm{pH} 7,9$ and 11, both yeast and $\mathrm{Fe}_{3} \mathrm{O}_{4}$ have negative charges and the adsorption performance of the bed increases very rapidly has the $\mathrm{pH}$ increases. The maximum equilibrium column capacity $(1221 \mathrm{mg} / \mathrm{g})$ and $\mathrm{MB}$ removal efficiency (63.4\%) appear at $\mathrm{pH} 11$, as also reported in other studies with other sorbents [39].

\subsection{Mathematical modeling of breakthrough curves}

Thomas [40] and Yoon-Nelson [41] models were used to model the experimental breakthrough curves at different influent dye concentration, flow rate, bed height and $\mathrm{pH}$. The linearized form of Thomas' model is widely used to describe column breakthrough data: 


$$
\ln \left(\frac{C_{0}}{C_{t}}-1\right)=\frac{k_{T h} q_{0} m}{F}-k_{T h} C_{0} t
$$

with $C_{0}$ and $C_{\mathrm{t}}$ the influent and effluent dye concentrations $(\mathrm{mg} / \mathrm{L}), k_{\mathrm{Th}}$ the Thomas rate constant $(\mathrm{mL} / \mathrm{min} \cdot \mathrm{mg}), q_{0}$ the equilibrium adsorption capacity $(\mathrm{mg} / \mathrm{g}), m$ the mass of the adsorbent $(\mathrm{g})$, and $F$ the solution flow rate $(\mathrm{mL} / \mathrm{min})$, respectively. The plots of $\ln \left[\left(C_{0} / C_{\mathrm{t}}\right)-1\right]$ versus time $(t)$ give a straight line of slope $\left(-k_{\mathrm{Th}} C_{0}\right)$ and intercept $\left(k_{\mathrm{Th}} q_{\mathrm{m}} \mathrm{m} / \mathrm{F}\right)$ (figure not shown).

The linearized form of Yoon-Nelson's model is:

$$
\ln \left(\frac{C_{\mathrm{t}}}{C_{0}-C_{\mathrm{t}}}\right)=k_{Y N} t-k_{Y N} \tau
$$

with the adsorption capacity in the Yoon-Nelson model calculated from [42]:

$$
q_{Y N}=\frac{q_{t o t}}{m}=\frac{C_{0} F \tau}{1000 m}
$$

with, $k_{\mathrm{YN}}$ the Yoon-Nelson rate constant $\left(\mathrm{min}^{-1}\right), \tau$ the time required for reaching $50 \%$ adsorbate breakthrough ( $\mathrm{min}$ ) and other parameters as above. The parameters $k_{\mathrm{YN}}$ and $\tau$ are determined from the slope and intercept of the linear plots of $\ln \left[C_{t}\left(C_{0}-C_{t}\right)\right]$ versus time $(t)$.

\section{Table 2}

Table 2 summarizes the model parameters determined from fitting the Thomas and Yoon-Nelson models to the experimental data. The rate constant $\left(k_{\mathrm{Th}}\right)$ in Table 2 , which characterizes the rate of solute transfer from the solution to the surface of solid, increased with increasing influent dye concentration and flow rate and decreased with bed height and $\mathrm{pH}$. These results support an increase of the importance of mass transfer limitations in the fixed bed as flow rate and dye concentration decreases and bed height and $\mathrm{pH}$ increases. The bed capacity $q_{0}$ calculated from Thomas' model decreased as the dye concentration, flow rate and bed height increased, because of intraparticle diffusion resistance. The values of $k_{\mathrm{YN}}$ increased with an increase in the influent dye concentration and flow rate, while the corresponding $\tau$ values followed an opposite trend. Moreover, the values of 
$k_{\mathrm{YN}}$ decreased with an increase in both bed height and $\mathrm{pH}$, whereas, a reverse trend was observed for the values of $\tau$.

The theoretical column adsorption capacities calculated from the Thomas and Yoon-Nelson models were compared to the experimental results (Figure S3 (a) (SI)). Here, it was observed that the theoretical column capacity predicted by the Yoon-Nelson model was closer to the experimental data. In addition, the experimental $\tau$ values and the theoretical $\tau$ values from Yoon-Nelson model were in close agreement (Figure S3 (b) (SI)). Thomas' model neglects external mass transfer and internal diffusion and assumes second-order reversible adsorption kinetics without axial dispersion. Therefore Thomas' model provided a closer fit only for the condition in which mass transfer could be considered negligible (Figure S3 (a) (SI) and Table 1). In contrast, the Yoon-Nelson model is based on the assumption that the rate of decrease in the probability of biosorption for each adsorbate molecule is proportional to the probability of adsorbate adsorption and the probability of adsorbate breakthrough on the biosorbent. The parameters in this model are adjustable and can fit experimental data that may have also been affected by external mass transfer resistances, internal diffusion and axial dispersion. In consequence, the Yoon-Nelson model provided a closer fit of the experimental data within the range of experimental conditions.

\subsection{Contaminant oxidation and sorbent regeneration}

The magnetic property imparted by the supported $\mathrm{Fe}_{3} \mathrm{O}_{4}$ on the yeast host is an important functionality. However, a more important functionality is the ability of $\mathrm{Fe}_{3} \mathrm{O}_{4}$ to trigger the heterogeneous Fenton oxidation reaction, which oxidizes the adsorbed contaminants regenerating the sorbent. The performance of the fixed-bed was evaluated for three consecutive adsorption/regeneration cycles. The influent $\mathrm{MB}$ concentration, flow rate, bed height and $\mathrm{pH}$ were fixed at $100 \mathrm{mg} / \mathrm{L}, 5 \mathrm{~mL} / \mathrm{min}, 1.2 \mathrm{~cm}$ 
and 7, respectively.

\section{Table 3}

The column capacity decreased after each regeneration cycle although MB uptake and removal rate remained very high (Table 3). The column bed exhibited equilibrium column loading capacities of over $273.5 \mathrm{mg} / \mathrm{g}$ dry beads and removal rate over $57.5 \%$ in all three cycles. The reduction in column capacity should be attributed to the inability of the Fenton reaction to remove MB sorbed deeply into the yeast cores, since $\mathrm{Fe}_{3} \mathrm{O}_{4}$ is primarily supported on the surface. Comparing the parameters $q_{\mathrm{e}}$ and $\varphi \%$ with those reported elsewhere [43-44], the $\mathrm{Fe}_{3} \mathrm{O}_{4} @$ yeast adsorbent presents the advantage that it can be easily regenerated in-situ and reused in multiple cycles.

Figure 5 shows the FT-IR spectra of (a) the synthesized $\mathrm{Fe}_{3} \mathrm{O}_{4} @$ yeast composite, (b) the $\mathrm{Fe}_{3} \mathrm{O}_{4} @$ yeast composite saturated by MB and (c) the saturated composites after Fenton-like reaction.

\section{Figure 5}

The spectra of the composite saturated with MB (trace b) displays new band peaks and some obvious red shift peaks in comparison to the fresh composite (trace a). The new bands peaks originated from the MB, particularly those at $1558,1396,1051$, and $578 \mathrm{~cm}^{-1}$ which correspond to the stretching vibrations of the aromatic ring, the $\mathrm{C}-\mathrm{C}$ and $\mathrm{C}-\mathrm{S}$ bonds, and the frame vibration of $\mathrm{C}-\mathrm{S}-\mathrm{C}$ [45]. The red shift peaks, such as the bands at $3292 \mathrm{~cm}^{-1}, 1641 \mathrm{~cm}^{-1}$ and $1054 \mathrm{~cm}^{-1}$, suggested the participation of -OH-, - $\mathrm{COO}-$, and $-\mathrm{OPO}_{3}{ }^{2-}$ groups in the adsorption reaction [46]. Notably, the bands associated with MB disappeared after the application of the Fenton-like reaction (trace c).

A schematic of the adsorption and in-situ regeneration mechanisms of the $\mathrm{Fe}_{3} \mathrm{O}_{4} @$ ayeast composite microspheres is presented in Figure S4 (b) (SI). The regeneration processes might be attributed to the synergistic effect, which works by integrating the biosorption properties of yeast with the catalytic 
oxidation properties of the supported $\mathrm{Fe}_{3} \mathrm{O}_{4}$ nanoparticles. Specifically, the MB molecules are firstly removed from aqueous solution by biosorption and pre-concentrated on the bare areas of the $\mathrm{Fe}_{3} \mathrm{O}_{4} @$ yeast composite microspheres. Then, the enriched MB molecules are decomposed by the $\mathrm{Fe}_{3} \mathrm{O}_{4} / \mathrm{H}_{2} \mathrm{O}_{2}$ Fenton-like oxidation reaction. The $\mathrm{H}_{2} \mathrm{O}_{2}$ introduced to the $\mathrm{MB}$ saturated column is catalytically decomposed by the supported $\mathrm{Fe}_{3} \mathrm{O}_{4}$ nanoparticles yielding $\bullet \mathrm{OH}$ radicals, which then attack the adsorbed MB molecules regenerating the sorbent. The targeted localized reaction at or in the close proximity of the composite surface is much more efficient than the same Fenton-like reaction carried out by $\mathrm{Fe}_{3} \mathrm{O}_{4}$ particles in suspensions in slurry reactors. Less catalyst is used, $\bullet \mathrm{OH}$ scavenging reactions species in solution are minimized (e.g., carbonates and not targeted species) and also the reaction acts on a much higher pollutant load, which increases the contaminant removal rate (i.e., first-order contaminant removal). In return, the regenerated surfaces of the yeast core can provide continuous adsorption sites for the biosorption of contaminants in repeated cycles.

\section{Conclusion}

In this study we have investigated a new composite material, which integrates the biosorption features of yeast cells with the magnetic and catalytic properties of $\mathrm{Fe}_{3} \mathrm{O}_{4}$ nanoparticles, for the effective removal and oxidative destruction of contaminants in water and wastewater. The raspberry-like $\mathrm{Fe}_{3} \mathrm{O}_{4} @$ yeast composite microspheres, were fabricated via a simple electrostatic self-assembly approach using inexpensive and abundant raw materials. These composites exhibited a ferromagnetic property that allows them to be easily separated/recovered by use of an external magnetic field. The adsorption and regeneration performance by a Fenton-like reaction of the microspheres was investigated for the continuous removal of the cationic dye methylene blue (MB) in an up-flow packed column. The adsorption process was controlled by the electrostatic interactions 
between the adsorbent and the contaminant. The adsorbent is suitable for the adsorption of positively charged compounds at mildly acidic $\mathrm{pH}$, neutral and alkaline $\mathrm{pH}$, with the highest performance observed at alkaline pH. The raspberry-like $\mathrm{Fe}_{3} \mathrm{O}_{4} @$ yeast composite material can be easily regenerated by applying a Fenton-like reaction and reused. Considering the facile method of fabrication of the composite from abundant and inexpensive raw materials, the easy recovery and separation in water, the superior adsorption performance, the simple and effective way of regeneration and the robustness of the adsorbent for consecutive adsorption/regeneration cycles, we conclude that the raspberry-like $\mathrm{Fe}_{3} \mathrm{O}_{4} @$ yeast magnetic microsphere should be a promising and practical adsorbent for removal and destruction of positively charged organic compounds in wastewater. The embedding of $\mathrm{Fe}_{3} \mathrm{O}_{4}$ onto the yeast surface can be extended to the simple fabrication of other $\mathrm{Fe}_{3} \mathrm{O}_{4}$ nanoparticles/bio-macromolecules or other magnetic oxides/yeast materials with similar structure.

\section{Associated Content}

Supporting Information

Additional information as noted in the text. This material is available free of charge via the Internet at http://link.springer.com.

\section{Acknowledgments}

This work was supported by China Postdoctoral Science Special Foundation, Scientific Research Foundation for the Returned Overseas Chinese Scholars, National Natural Science Foundation of China (No.21176031) and Fundamental Research Funds for the Central Universities (No. 2013G2291015). 


\section{References}

[1] R.C. Wu, J.H. Qu, Water Environ. Res. 2004, 76, 2637-2642.

[2] P. Kovacic, R. Somanathan, J. Appl. Toxicol. 2014, 34, 825-834.

[3] P. Drogui, J.F. Blais, Recent Patents on Engineering. 2007, 1, 257-272.

[4] M. Solís, A. Solís, H.I. Pérez, N. Manjarrez, M. Flores, Process Biochem. 2012, 47, 1723-1748.

[5] V. Janaki, K. Vijayaraghavan, A.K. Ramasamy, K.J. Lee, B.T. Oh, S. Kamala-Kannan, J. Hazard. Mater. 2012, 241-242, 110-117.

[6] A.H. Chen, S.M. Chen, J. Hazard. Mater. 2009, 172, 1111-1121.

[7] J.X. Yu, R.A. Chi, X.Z. Su, Z.Y. He, Y.F. Qi, Y.F. Zhang, J. Hazard. Mater. 2010, 177, 222-227.

[8] M.L. Rache, A.R. García, H.R. Zea, A.M.T. Silva, L.M. Madeira, J.H. Ramírez, Appl. Catal. B: Environ. 2014, 146, 192-200.

[9] L. Gu, S. Huang, N. Zhu, D. Zhang, H. Yuan, Z. Lou, J. Hazard. Mater. 2013, 263, 450-457.

[10] A.D.L. Maria, S. Marta, B. Juan, React Kinet. Mech. Cat. 2013, 110, 101-117.

[11] X. Liang, Y. Zhong, S. Zhu, J. Zhu, P. Yuan, H. He, J. Zhang, J. Hazard. Mater. 2010, 181, $112-120$.

[12] S. Xavier, R. Gandhimathi, P.V. Nidheesh, S.T. Ramesh, Desalination and Water Treatment. DOI:10.1080/19443994.2013.844083.

[13] R.C. Wu, J.H. Qu, Water Environ. Res. 2004, 76, 2637-2642.

[14] S.H. Kong, R.J. Watts, J. H. Choi, Chemosphere. 1998, 37, 1473-1482.

[15] B.W. Tyre, R.J. Watts, G.C. Miller, J. Environ. Qual. 1991, 20, 832-838.

[16] S.J. Guo, S.J. Dong, E.K. Wang, J. Phys. Chem. C. 2009, 113, 5485-5492.

[17] L. Zhang, Y. Li, J.Q. Sun, J.C. Shen, Langmuir. 2008, 24, 10851-10857. 
[18] H.L. Liu, D. Wang, X.L. Yang, Colloids Surf. A: Physicochem. Eng. Asp. 2012, 397, 48-58.

[19] X. Wang, T. Akagi, M. Akashi, B. Masanori, Mini-Rev. Org. Chem. 2007, 4, 51-59.

[20] H.J. Tsai, Y.L. Lee, Langmuir. 2007, 23, 12687-12692.

[21] B. Bai, N. Quici, Z.Y. Li, G.L. Puma, Chem. Eng. J. 2011, 170, 451-456.

[22] S.X. Zhang, X.L. Zhao, H.Y. Niu, Y.L. Shi, Y.Q. Cai, G.B. Jiang, J. Hazard. Mater. 2009, 167, $560-566$.

[23] T. Zhu, J.S. Chen, X.W. Lou (David), J. Phys. Chem. C. 2011, 115, 9814-9820.

[24] L.F. Duan, S.S. Jia, Y.J. Wang, J. Chen, L.J. Zhao, J Mater. Sci. 2009, 44, 4407-4412.

[25] N.S. Kim, J.D. Kim, J. Ind. Eng. Chem. 2012, 18, 1721-1729.

[26] X.D. Su, J.Z. Zhao, Y.L. Li, Y.C. Zhu, X.K. Ma, F. Sun, Z.C. Wang, Colloids Surf. A: Physicochem. Eng. Asp. 2009, 349, 151-155.

[27] M.S. Hassan, T. Amna, O.B. Yang, H.C. Kim, M.S. Khil, Ceram. Int. 2012, 38, 5925-5930.

[28] Z.P. Li, L. Gao, S. Zheng, Appl. Catal. A: Gen. 2002, 236, 163-171.

[29] S. Kumar, T. Surendar, B. Kumar, A. Baruah, V. Shanker, J. Phys. Chem. C. 2013, 117, $26135-26143$.

[30] J.J. Cui, W. He, H.T. Liu, S.J. Liao, Y.Z. Yue, Colloids Surf. B. 2009, 74, 274-278.

[31] K.C. Blakeslee, A. Robert, S.R. Condrate, J. Am. Ceram. Soc. 1971, 54, 559-563.

[32] S.J. Joris, C.H. Amberg, J. Phys. Chem. 1971, 75, 3172-3178.

[33] Y.C. Chang, D.H. Chen, J. Colloid Interf. Sci. 2005, 283, 446-451.

[34] M. Mercier-Bonin, K. Ouazzani, P. Schmitz, S. Lorthois, J. Colloid Interf. Sci. 2004, 271, $342-350$.

[35] J.L. Wang, C. Chen, Biotechnol. Adv. 2009, 27, 195-226. 
[36] S. Mann, D.D. Archibald, J.M. Didymus, T. Douglas, B.R. Heywood, F.C. Meldrum, N.J. Reeves, Science. 1993, 261, 1286-1292.

[37] L.H. Ai, H.Y. Huang, Z.L. Chen, Wei, X.; Jiang, J. Chem. Eng. J. 2010, 156, 243-249.

[38] M.A.M. Salleh, D.K. Mahmoud, W.A.W.A. Karim, A. Idris, Desalination. 2011, 280, 1-13.

[39] M. Doğan, M. Alkan, Chemosphere. 2003, 50, 517-528.

[40] H.C. Thomas, J. Am. Chem. Soc. 1944, 66, 1664-1666.

[41] Y.H. Yoon, J.H. Nelson, Am. Ind. Hyg. Assoc. J. 1984, 45, 509-516.

[42] S.H. Hasan, D. Ranjan, M. Talat, J. Hazard. Mater. 2010, 181, 1134-1142.

[43] D. Kavitha, C. Namasivayam, Bioresour. Technol. 2007, 98, 14-21.

[44] L. Chen, B. Bai, Ind. Eng. Chem. Res. 2013, 52, 15568-15577.

[45] L.H. Ai, C.Y. Zhang, F. Liao, Y. Wang, M. Li, L.Y. Meng, J. Jiang, J. Hazard. Mater. 2011, 198, $282-290$.

[46] S.V. Mohan, S.K. Mohan, M.J. Kathikeyan, J. Sci. Ind. Res. 2001, 60, 410- 415. 


\section{Figure captions}

Figure1. FE-SEM images of (a) the originalyeast, (b and c) $\mathrm{Fe}_{3} \mathrm{O}_{4} @$ yeast microspheres observed under different magnifications.

Figure 2.XRD patterns of (a) the original yeast,(b) $\mathrm{Fe}_{3} \mathrm{O}_{4}$ nanoparticles, and (c) $\mathrm{Fe}_{3} \mathrm{O}_{4} @$ yeast compositemicrospheres.

Figure 3.FT-IR spectrum of (a) the $\mathrm{Fe}_{3} \mathrm{O}_{4} \mathrm{NPs}$, (b) the pristine of yeast and (c) $\mathrm{Fe}_{3} \mathrm{O}_{4} @$ yeast composite microspheres.

Figure 4. The breakthrough curves for $\mathrm{MB}$ adsorption by $\mathrm{Fe}_{3} \mathrm{O}_{4} @$ ayeast composites (a) at different influent dye concentration (flow rate $=5 \mathrm{~mL} / \mathrm{min}$, bed height $=1.2 \mathrm{~cm}$, and $\mathrm{pH}=7.0$ ), (b) at different flow rate (influent dye concentration $=100 \mathrm{mg} / \mathrm{L}$, bed height $=1.2 \mathrm{~cm}$, and $\mathrm{pH}$ $=7.0$ ), (c) at different bed height (influent dye concentration $=100 \mathrm{mg} / \mathrm{L}$, flow rate $=5$ $\mathrm{mL} / \mathrm{min}$, and $\mathrm{pH}=7.0$ ) and (d) at different $\mathrm{pH}$ (influent dye concentration $=100 \mathrm{mg} / \mathrm{L}$, flow rate $=5 \mathrm{~mL} / \mathrm{min}$, and bed height $=1.2 \mathrm{~cm}$ ).

Figure 5. FT-IR spectra of (a) $\mathrm{Fe}_{3} \mathrm{O}_{4} @$ yeast composites, (b) the $\mathrm{Fe}_{3} \mathrm{O}_{4} @$ yeast composites saturated by MB and (c) the saturated composites after Fenton-like reaction. 
Figure 1.
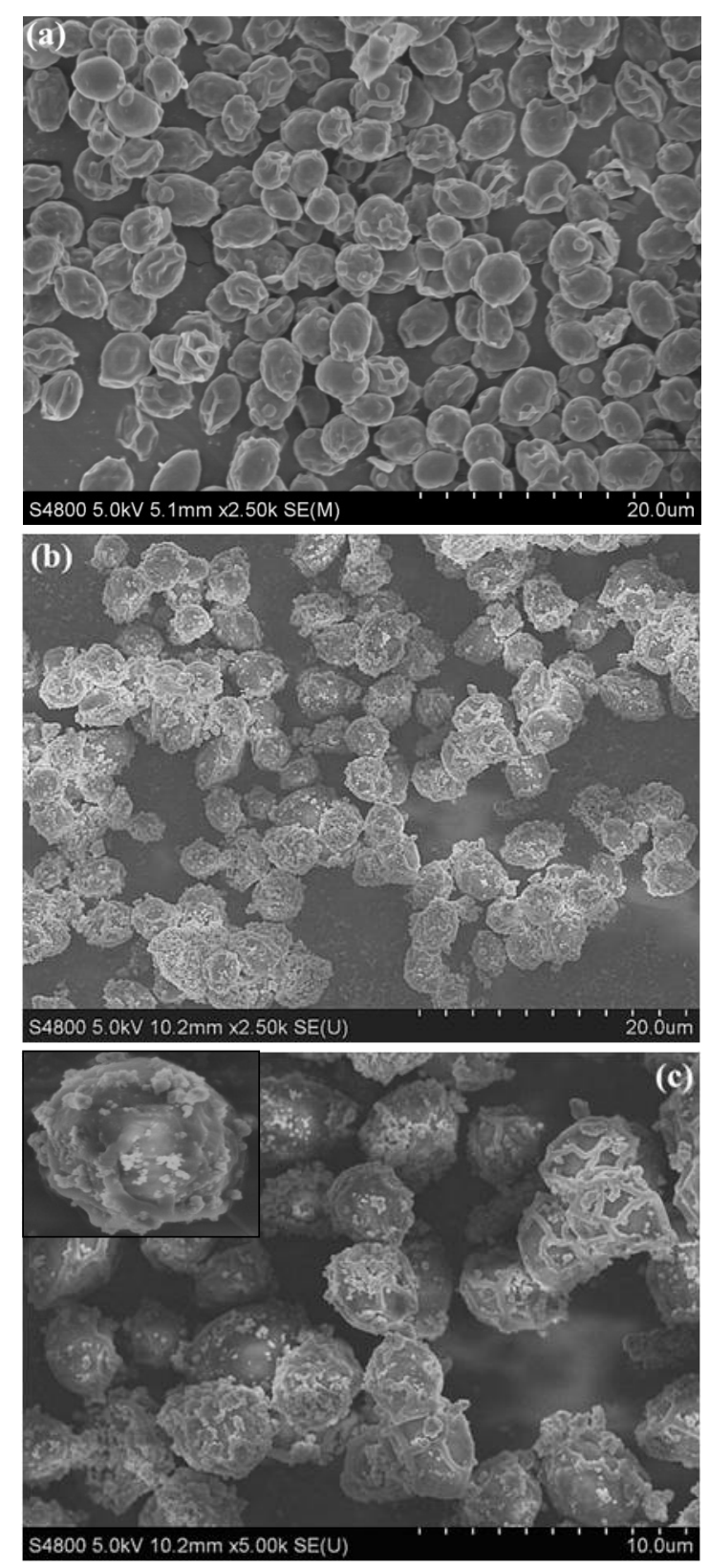
Figure 2.

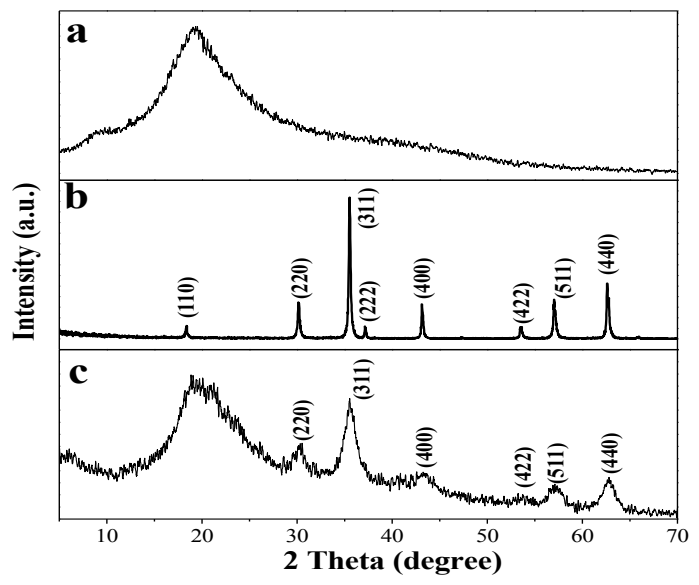


Figure 3.

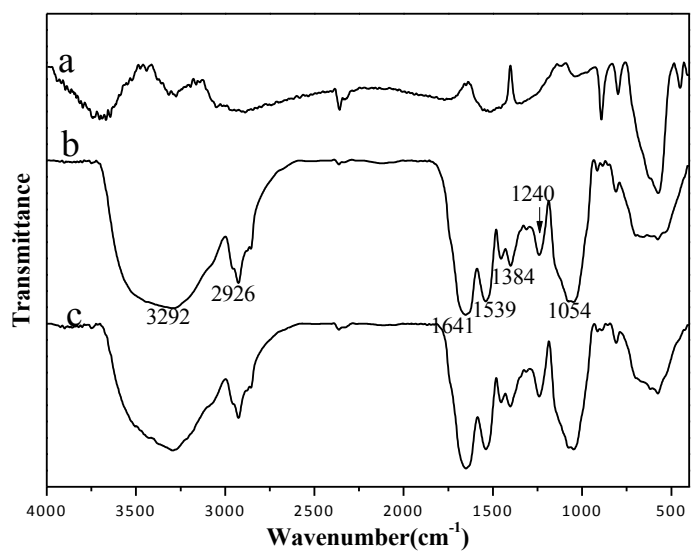


Figure 4.
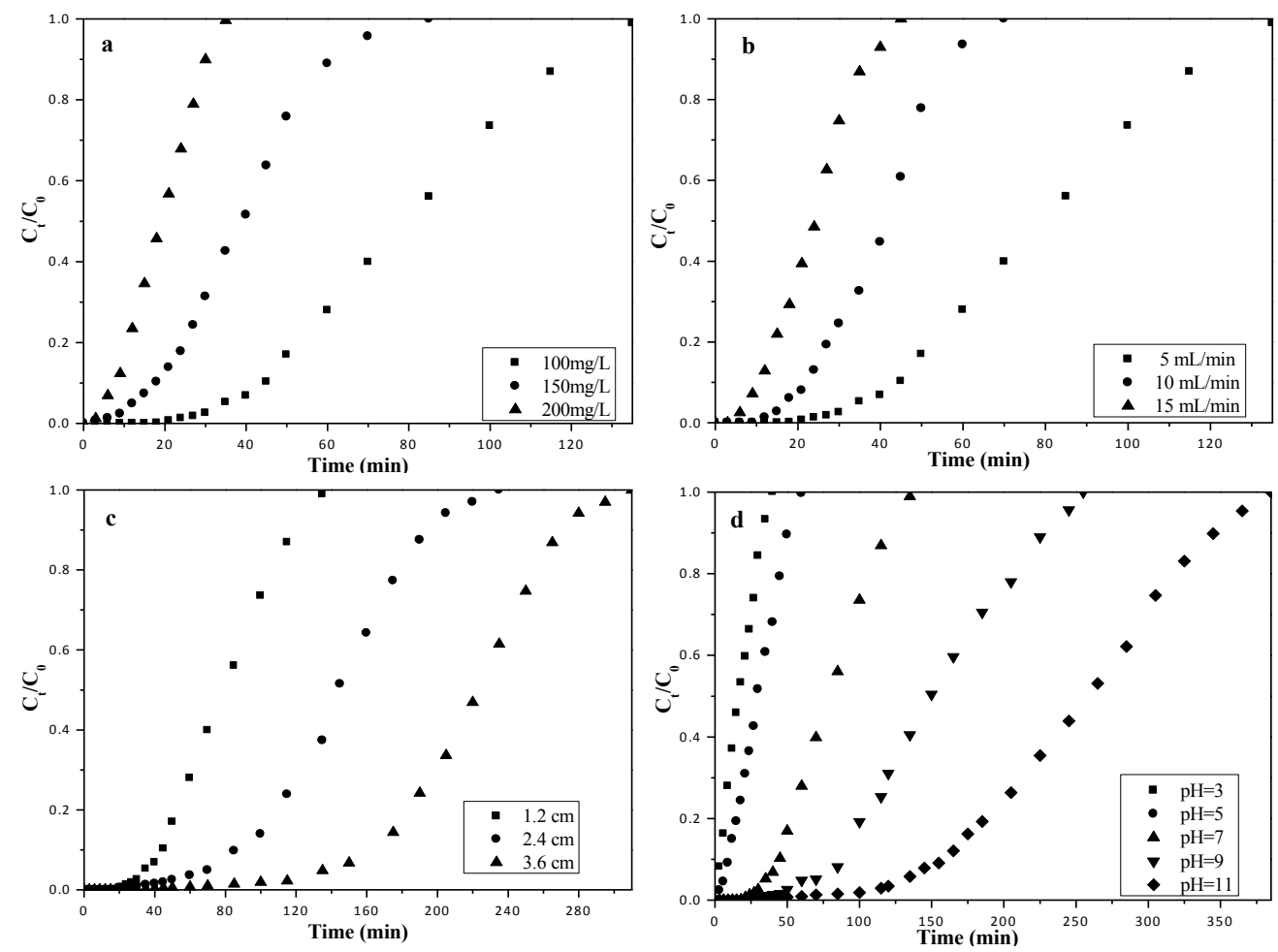
Figure 5.

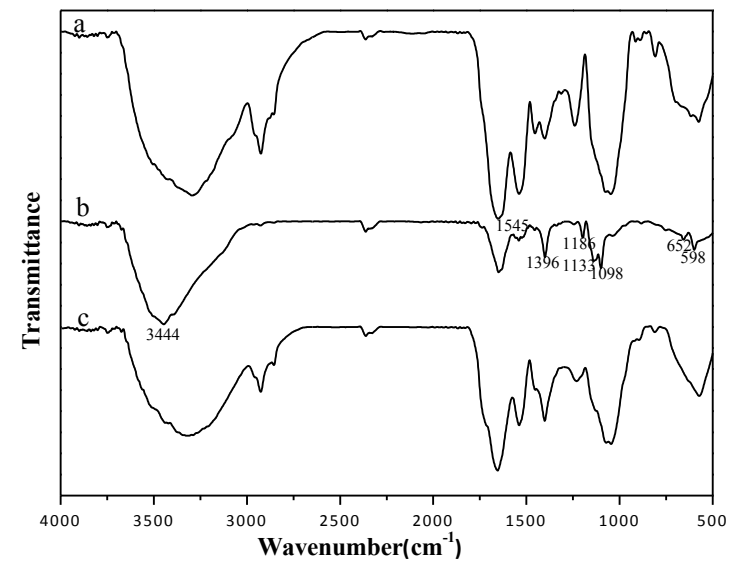




\section{Table captions}

Table 1.Column data and parameters obtained at different conditions.

Table 2. Parameters predicted from the Thomas and Yoon-Nelson models.

Table 3. Column data and parameters obtained after Fenton-like regeneration. 
Table 1.

\begin{tabular}{|c|c|c|c|c|c|c|c|}
\hline $\begin{array}{c}\text { Process } \\
\text { parameters }\end{array}$ & $t_{\mathrm{b}}(\min )$ & $t_{\mathrm{e}}(\min )$ & $V_{\text {eff }}(\mathrm{mL})$ & $q_{\mathrm{tot}}(\mathrm{mg})$ & $m_{\mathrm{tot}}(\mathrm{mg})$ & $\begin{array}{c}\text { Dye removal } \\
\qquad \varphi \%\end{array}$ & $q_{\mathrm{e}}(\mathrm{mg} / \mathrm{g})$ \\
\hline \multicolumn{8}{|c|}{ Initial dye concentration, $C_{0}(\mathrm{mg} / \mathrm{L})(F=5 \mathrm{~mL} / \mathrm{min}, Z=1.2 \mathrm{~cm}, \mathrm{pH}=7.0)$} \\
\hline 100 & 24 & 135 & 675 & 40.1 & 67.5 & 59.3 & 400.5 \\
\hline 150 & 6 & 70 & 350 & 29.4 & 52.5 & 56.0 & 294.0 \\
\hline 200 & 3 & 35 & 175 & 19.1 & 35.0 & 54.6 & 191.1 \\
\hline \multicolumn{8}{|c|}{ Flow rate, $F(\mathrm{~mL} / \mathrm{min})\left(C_{0}=100 \mathrm{mg} / \mathrm{L}, Z=1.2 \mathrm{~cm}, \mathrm{pH}=7.0\right)$} \\
\hline 5 & 24 & 135 & 675 & 40.1 & 67.5 & 59.3 & 400.5 \\
\hline 10 & 18 & 85 & 650 & 35.5 & 65.0 & 54.6 & 355.0 \\
\hline 15 & 9 & 35 & 630 & 31.1 & 63.0 & 49.3 & 310.9 \\
\hline \multicolumn{8}{|c|}{ Bed height, $Z(\mathrm{~cm})\left(C_{0}=100 \mathrm{mg} / \mathrm{L}, F=5 \mathrm{~mL} / \mathrm{min}, \mathrm{pH}=7.0\right)$} \\
\hline 1.2 & 24 & 135 & 675 & 40.1 & 67.5 & 59.3 & 400.5 \\
\hline 2.4 & 85 & 235 & 1175 & 74.2 & 117.5 & 63.1 & 370.8 \\
\hline 3.6 & 150 & 310 & 1550 & 108.8 & 155.0 & 70.2 & 362.8 \\
\hline \multicolumn{8}{|c|}{$\mathrm{pH}\left(C_{0}=100 \mathrm{mg} / \mathrm{L}, F=5 \mathrm{~mL} / \mathrm{min}, Z=1.2 \mathrm{~cm}\right)$} \\
\hline 3 & 6 & 40 & 200 & 9.9 & 20.0 & 49.5 & 99.0 \\
\hline 5 & 12 & 60 & 300 & 15.2 & 30.0 & 50.5 & 151.5 \\
\hline 7 & 24 & 135 & 675 & 40.0 & 67.5 & 59.3 & 400.5 \\
\hline 9 & 35 & 255 & 1275 & 78.0 & 127.5 & 61.2 & 780.1 \\
\hline 11 & 70 & 385 & 1925 & 122.1 & 192.5 & 63.4 & 1221.0 \\
\hline
\end{tabular}


Table 2.

\begin{tabular}{|c|c|c|c|c|c|c|}
\hline \multirow[t]{2}{*}{ Parameters } & \multicolumn{3}{|c|}{ Thomas model } & \multicolumn{3}{|c|}{ Yoon-Nelson model } \\
\hline & $\begin{array}{c}k_{\mathrm{Th}} \\
(\mathrm{mL} / \mathrm{min} \cdot \mathrm{mg})\end{array}$ & $q_{0}(\mathrm{mg} / \mathrm{g})$ & $R^{2}$ & $k_{\mathrm{YN}} \times 10^{-3}\left(\mathrm{~min}^{-1}\right)$ & $\tau(\min )$ & $R^{2}$ \\
\hline \multicolumn{7}{|c|}{ Initial dye concentration $(\mathrm{mg} / \mathrm{L})$} \\
\hline 100 & 7.29 & 396.3 & 0.97 & 72.9 & 79.2 & 0.97 \\
\hline 150 & 8.68 & 254.2 & 0.98 & 130.2 & 33.9 & 0.98 \\
\hline 200 & 12.49 & 153.8 & 0.90 & 249.7 & 15.3 & 0.90 \\
\hline \multicolumn{7}{|c|}{ Flow rate $(\mathrm{mL} / \mathrm{min})$} \\
\hline 5 & 7.29 & 396.3 & 0.97 & 72.9 & 79.2 & 0.97 \\
\hline 10 & 13.44 & 382.4 & 0.98 & 134.4 & 38.2 & 0.98 \\
\hline 15 & 17.36 & 359.9 & 0.98 & 173.6 & 23.9 & 0.98 \\
\hline \multicolumn{7}{|c|}{ Bed height (cm) } \\
\hline 1.2 & 7.29 & 396.3 & 0.97 & 72.9 & 79.2 & 0.97 \\
\hline 2.4 & 4.10 & 365.4 & 0.99 & 49.2 & 131.7 & 0.99 \\
\hline 3.6 & 3.38 & 357.5 & 0.98 & 33.8 & 214.5 & 0.98 \\
\hline \multicolumn{7}{|l|}{$\mathrm{pH}$} \\
\hline 3 & 14.01 & 88.2 & 0.97 & 140.1 & 17.6 & 0.97 \\
\hline 5 & 11.10 & 152.8 & 0.96 & 111.0 & 30.5 & 0.96 \\
\hline 7 & 7.29 & 396.3 & 0.97 & 72.9 & 79.2 & 0.97 \\
\hline 9 & 3.86 & 754.5 & 0.98 & 38.6 & 150.8 & 0.98 \\
\hline 11 & 2.42 & 1265.3 & 0.99 & 24.2 & 253.1 & 0.99 \\
\hline
\end{tabular}


Table 3.

\begin{tabular}{cccccccc}
\hline Cycle time & $t_{\mathrm{b}}$ & $t_{\mathrm{e}}$ & $\mathrm{V}_{\text {eff }}(\mathrm{mL})$ & $q_{\text {tot }}(\mathrm{mg})$ & $m_{\text {tot }}(\mathrm{mg})$ & Dye removal $\varphi \%$ & $q_{\mathrm{e}}(\mathrm{mg} / \mathrm{g})$ \\
\hline $1^{\text {th }}$ & 24 & 135 & 675 & 40.1 & 67.5 & 59.3 & 400.5 \\
$2^{\text {th }}$ & 18 & 115 & 500 & 33.8 & 57.5 & 58.7 & 337.5 \\
$3^{\text {th }}$ & 12 & 95 & 300 & 27.4 & 47.5 & 57.6 & 273.5 \\
\hline
\end{tabular}




\section{Supporting Information of Figures}

Figure S1. EDS spectra of $\mathrm{Fe}_{3} \mathrm{O}_{4} @$ yeast composite microspheres.

Figure S2. Photographs of the dispersion and separation processes of $\mathrm{Fe}_{3} \mathrm{O}_{4} @$ yeast: (a) without external magnetic field, and (b) with external magnetic field.

Figure S3.Models fitting of experimental (a) column capacity $q(\mathrm{mg} / \mathrm{g}$ ) and (b) the $50 \%$ adsorbate breakthrough time $\tau(\min )$.

Figure S4.Proposed mechanism of (a) formation and (b) the in situ heterogeneous Fenton-like regeneration of $\mathrm{Fe}_{3} \mathrm{O}_{4} @$ yeast composites. 
Figure S1.

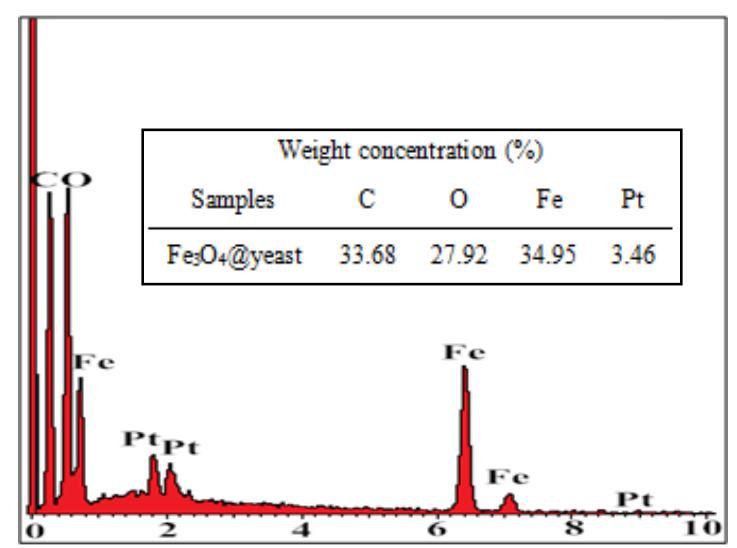


Figure S2.

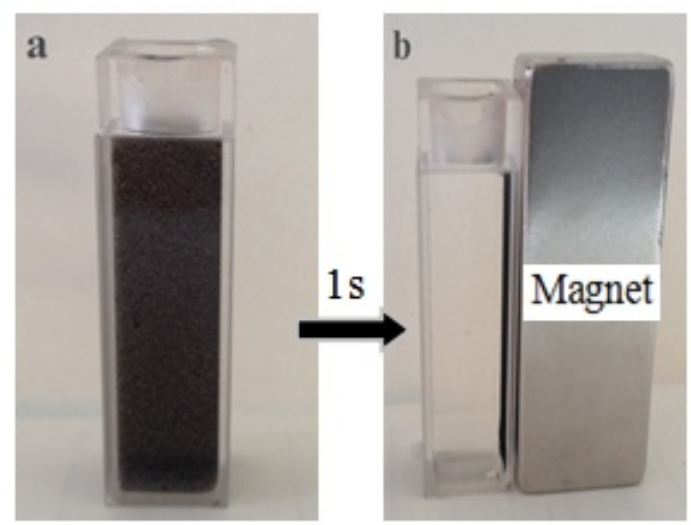


Figure S3.
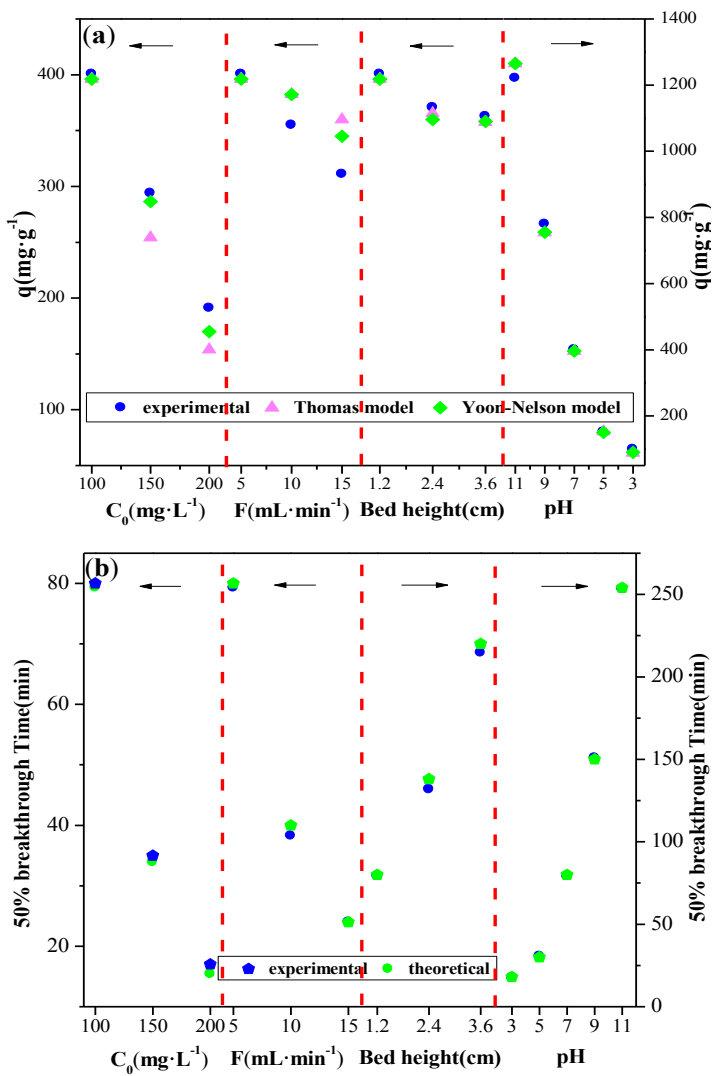
Figure S4.

(a)

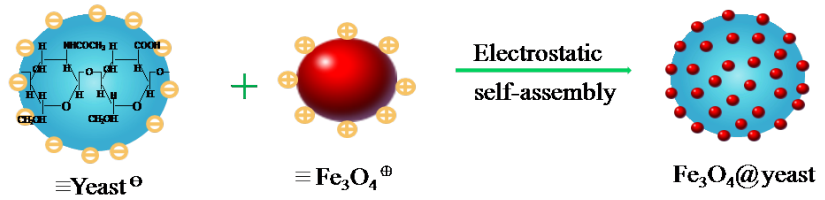

(b)

$$
\left(\begin{array}{c}
-\mathrm{NH}-,-\mathrm{CH}_{2}-, \\
-\mathrm{COO}-,
\end{array}\right.
$$
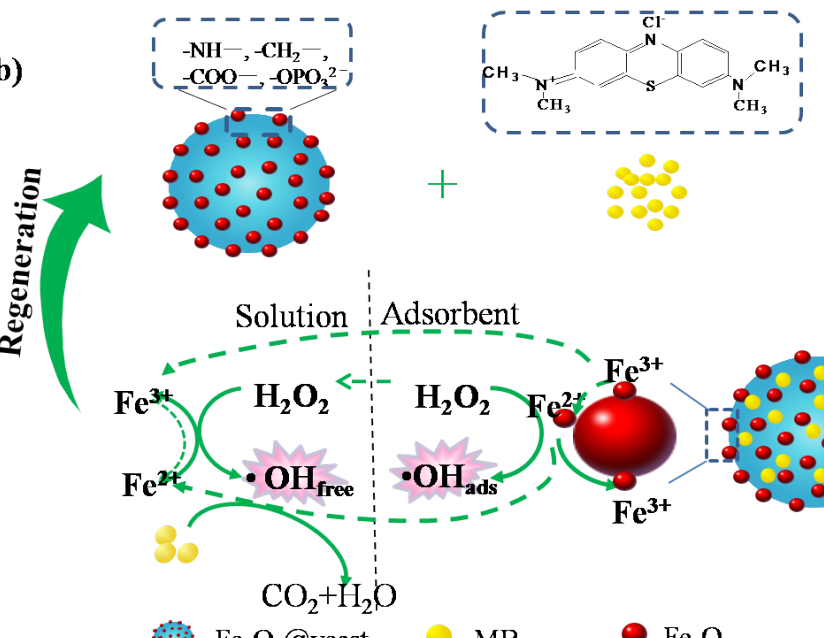

Fe $\mathrm{Fe}_{3} @$ yeast

- MB

- $\mathrm{Fe}_{3} \mathrm{O}_{4}$ 